\title{
Aleksandra Siedlaczek-Szwed, Działalność opiekuńcza towa- rzystw dobroczynnych na Wileńszczyźnie w Drugiej Rzeczypospoli- tej, Wydawnictwo Akademii im. Jana Długosza w Częstochowie, Częstochowa 2009, ss. 288
}

Dzieje opieki i pomocy społecznej na ziemiach polskich to tematyka, która wciąż nie cieszy się zbyt dużym zainteresowaniem badaczy. Stąd też szczególną wartość ma wydana w tym roku książka Aleksandry Siedlaczek-Szwed poświęcona międzywojennym towarzystwom dobroczynnym na Wileńszczyźnie. Publikacja ta jest kontynuacją zainteresowań autorki problematyką opieki na Kresach, które znalazły wyraz m.in. w jej książce Wileńskie Towarzystwo Opieki nad Dziećmi w latach 1901-1940 (Częstochowa 1998).

Praca, której głównym materiałem badawczym były artykuły prasowe oraz archiwalia, składa się z pięciu rozdziałów, a zagadnienia opieki z lat 1918-1939 przedstawione są w nich w sposób problemowy. Ponadto książka posiada obszerną bibliografię oraz kilkudziesięciostronicowy aneks, gdzie Autorka prezentuje fragment materiału badawczego: wykaz towarzystw dobroczynnych, działających na Wileńszczyźnie w Drugiej Rzeczypospolitej oraz pięć przykładowych statutów takich organizacji.

Jak badaczka zaznaczyła we „Wstępie”, podjęcie się opracowania miało za cel dokonanie rekonstrukcji przyczyn i okoliczności roztoczenia opieki społecznej nad małoletnim dzieckiem osieroconym lub pozbawionym właściwej opieki ze strony rodziny, wskazanie bodźców przyczyniających się do rozwoju idei opiekuńczych na przestrzeni omawianego czasu oraz ujawnienie mechanizmów powodujacych doskonalenie i rozszerzenie działalności, dokonanie oceny pracy opiekuńczo-wychowawczej na tle potrzeb społecznych, uszczegółowienie kryteriów stawianych instytucjom opieki nad dzieckiem $w$ warunkach Drugiej Rzeczypospolitej.

Rozdział pierwszy jest poświęcony specyficznym uwarunkowaniom determinującym działalność opiekuńczo-wychowawczą na Wileńszczyźnie, która w okresie II RP wyróżniała się trudną sytuacją polityczno-społeczną oraz zróżnicowaniem narodowościowym. Ukazany został rys historyczny stosunków pomiędzy mieszkańcami tych terenów, zróżnicowanych pod względem narodowościowym: Polakami, Żydami, Białorusinami, Litwinami. Autorka omówiła tę problematykę w sposób bardzo skrótowy, niemniej jednak wydaje się, że wystarczający do zrozumienia stosunków społecznych i ich konsekwencji dla działalności dobroczynnej.

Drugi rozdział jest poświęcony organizacjom społecznym działającym na rzecz opieki i wychowania dziecka. Autorka ukazuje sytuację na Wileńszczyźnie w bardzo szerokim kontekście uwarunkowań społeczno-ekonomicznych dla powstawania instytucji opiekuńczych na terenie całego kraju i przemian w zakresie ustawodawstwa oraz konkretnych rozwiązań praktycznych, jakie były realizowane w Drugiej Rzeczypospolitej. Kontynuując wątek wielonarodowościowego charakteru Ziemi Wileńskiej, oprócz polskich omawia również instytucje żydowskie oraz prawosławne.

W trzecim rozdziale zostają omówione główne nurty wychowawcze, które miały wpływ na działalność opiekuńczą w okresie międzywojennym, m.in. wychowanie naro- 
dowe i państwowe. Autorka przedstawia kolejne koncepcje w wymiarze teoretycznym oraz praktycznym - ukazując konkretne osoby i instytucje, które wprowadzały je w życie. Wśród wielu stowarzyszeń szczególna uwaga została poświęcona Polskiej Macierzy Szkolnej i jej rozległej działalności na gruncie oświatowo-opiekuńczym.

Dwa ostatnie rozdziały zapoznają Czytelnika z praktycznymi stronami funkcjonowania organizacji opiekuńczo-wychowawczych. W czwartym zaprezentowano podstawy ekonomiczne ich funkcjonowania. Badając materiały archiwalne kilkudziesięciu wileńskich organizacji, autorka ukazuje różnorodność rozwiązań w pozyskiwaniu środków oraz zarządzaniu majątkami, a także trudności w tym zakresie, spowodowane choćby kryzysem ekonomicznym.

Ostatni rozdział poświęcony jest członkom i władzom towarzystw opiekuńczo-wychowawczych, którymi w większości byli społecznicy i filantropi. Oprócz wymienienia najbardziej zasłużonych działaczy ukazana zostaje struktura i różnorodne zasady funkcjonowania wileńskich organizacji dobroczynnych.

Praca Aleksandry Siedlaczek-Szwed nie wyczerpuje oczywiście tematu instytucji dobroczynnych na Wileńszczyźnie, ponieważ z uwagi na bogate tradycje w tej dziedzinie, niejedna $z$ omawianych organizacji wymagałaby sporządzenia oddzielnej monografii. Czytelnik ma okazję zaznajomić się z dużym zróżnicowaniem, jakie w Polsce międzywojennej występowało wśród organizacji zajmujących się pomocą potrzebującym oraz charakterystycznymi dla Ziemi Wileńskiej problemami politycznymi i narodowościowymi. Trzeba podkreślić duży wkład pracy Autorki w uporządkowanie materiału - zaprezentowanie zawartości zasobów archiwalnych oraz wielu czasopism, dzięki którym jest możliwa rekonstrukcja jakże chlubnych działań polskich filantropów. Warto również oczekiwać kolejnych publikacji dotyczących organizacji dobroczynnych, które często - mimo wielu lat swojej działalności - nie zostały jeszcze ujęte w opracowaniach historycznych.

Mikołaj Brenk

\section{Władysława Szulakiewicz, Historia wychowania w Uniwersytecie im. Adama Mickiewicza, Warszawa 2007, ss. 47}

Historia wychowania jest swoista dyscyplina stykowa, która oscyluje [...] zarówno $w$ aspekcie organizacji nauki, jak $i w$ wyborze problematyki naukowo-badawczej oraz warsztatu naukowo-badawczego itp., bardziej ku pedagogice niz ku historii ${ }^{1}$. Jej początki sięgają XIX w. i co warto podkreślić, związane są z Poznaniem (!). W 1841 r. po raz pierwszy wydano w Poznaniu Stan oświecenia $w$ Polsce $w$ ostatnich latach panowania Augusta III (1750-1764) Hugo Kołłątaja, którego uważa się - dość powszechnie - za

\footnotetext{
${ }^{1}$ J. Hellwig, Dzieje historii wychowania w Polsce i jej twórcy, Poznań 2001, s. 10.
} 